\title{
CONCURRENT DEEP VEIN THROMBOSIS AND PULMONARY EMBOLISM ASSOCIATED WITH HYPERTHYROIDISM: A CASE REPORT
}

\author{
Josip Katić ${ }^{1}$, Ana Katić 2 , Karla Katić ${ }^{3}$, Darko Duplančić ${ }^{1}$ and Mislav Lozo ${ }^{1}$ \\ ${ }^{1}$ Department of Cardiology, Split University Hospital Centre, Split, Croatia; \\ ${ }^{2}$ University of Split School of Medicine, Split, Croatia; \\ ${ }^{3}$ Department of Ophthalmology, Split University Hospital Centre, Split, Croatia
}

\begin{abstract}
SUMMARY - Numerous disorders of coagulation and fibrinolysis have been reported in patients with thyroid diseases, especially with hyperthyroidism. Most articles are focused on deep vein thrombosis risk, however, few of them describe association between hyperthyroidism and pulmonary embolism. We report a case of a 43-year-old woman with long-term uncontrolled hyperthyroidism complicated by venous thromboembolism. The potential mechanisms could be endothelial dysfunction, decreased fibrinolytic activity, and increased levels of coagulation factors. Thyroid evaluation should be recommended in patients with unprovoked venous thromboembolic events.
\end{abstract}

Key words: Hyperthyroidism; Pulmonary embolism; Venous thromboembolism; Deep vein thrombosis

\section{Introduction}

Acute venous thromboembolism (VTE), defined as deep vein thrombosis (DVT) or pulmonary embolism, ranks third in the number of deaths caused by cardiovascular diseases ${ }^{1}$. Due to nonspecific symptoms of pulmonary embolism, diagnosis is hard to achieve since it manifests in a wide spectrum of clinical presentations, from asymptomatic to cardiogenic shock ${ }^{2}$. Virchow's triad describes three broad categories of factors that contribute to thrombosis, i.e. hypercoagulation, stasis, and damage to blood vessel endothelium. Thyroid dysfunction is a disorder that affects nearly $11 \%$ of Europeans, half of whom are not aware of their condition $^{3}$. An overactive thyroid, also known as hyperthyroidism or thyrotoxicosis, is a condition where thyroid gland produces too much of thyroid hormones. Previous studies have shown a hypercoagulable and

Correspondence to: Josip Katic, MD, Department of Cardiology, Split University Hospital Centre, Spinčićeva 1, HR-21000 Split, Croatia

E-mail: josipkati@gmail.com

Received May 27, 2020, accepted September 30, 2020 hypofibrinolytic state in patients with hyperthyroidism, which may contribute to the increased risk of thromboembolism ${ }^{3}$. We present a rare case of a patient with DVT and pulmonary embolism accompanied by uncontrolled hyperthyroidism.

\section{Case Report}

A 43-year-old female was examined in the emergency department due to swelling of her right leg, which had started four days before admission, as well as shortness of breath, exercise intolerance, and dry cough. Over the last 18 years, she had been treated intermittently for hyperthyroidism. Three months before, she had stopped taking thiamazole and propranolol, and denied taking any other medication. Her body mass index was $23.8 \mathrm{~kg} / \mathrm{m}^{2}$, blood pressure $105 / 75 \mathrm{~mm} \mathrm{Hg}$, and heart rate 110 beats per minute. She was mildly somnolent, conscious, mildly dehydrated, and febrile $\left(38.2^{\circ} \mathrm{C}\right)$. Her right leg was swollen, warm, painful on palpation, with tight skin. Laboratory tests revealed elevated $\mathrm{D}$-dimer and decreased partial oxygen pressure $\left(\mathrm{pO}_{2}\right)$ and oxygen saturation $\left(\mathrm{SaO}_{2}\right)$ levels. High-sensi- 


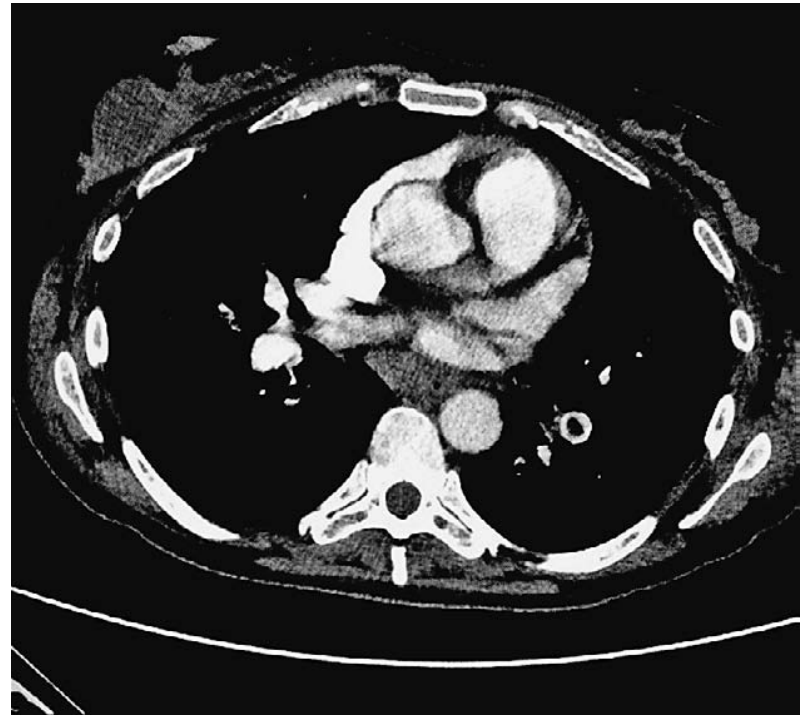

Fig. 1. Computed tomography angiography of pulmonary arteries showed a 33-mm thrombus in the left pulmonary artery.

tivity troponin I was increased. Echocardiographic findings revealed a dilated right ventricle and left atrium, preserved systolic function and impaired diastolic function, with severe pulmonary hypertension and estimated pulmonary pressure of $90 \mathrm{~mm} \mathrm{Hg}$. Emergency computed tomography angiography of pulmonary arteries confirmed pulmonary embolism (Fig. 1).

Pulmonary embolism was classified as intermediate-high risk according to the latest European Society of Cardiology guidelines ${ }^{4}$. Doppler ultrasound examination of the right leg confirmed DVT. She was diagnosed with Graves' disease based on the presence of goiter, exophthalmos, and hyperthyroidism with thyroid-stimulating hormone (TSH) receptor antibody positivity. The patient was hospitalized and therapy with low-molecular weight heparin was immediately initiated, which was later replaced with vitamin $\mathrm{K}$ antagonist therapy. An extended systematic and multidisciplinary investigation (tumor markers, abdominal multi-slice computed tomography, thrombophilia panel, antiphospholipid antibodies, protein $\mathrm{C}$ and $\mathrm{S}$, antithrombin, anticardiolipin antibodies and hyperhomocysteinemia) did not reveal the possible underlying cause of the thromboembolic incident. However, the extremely low TSH level of $0.001 \mu \mathrm{U} / \mathrm{mL}$ (reference range $0.4-4.5 \mu \mathrm{U} / \mathrm{mL}$ ) was recorded, accompanied by a free thyroxine (fT4) level of $50.98 \mathrm{pmol} / \mathrm{L}$ (reference range $12-22 \mathrm{pmol} / \mathrm{L})$. Treatment with thiamazole was reintroduced and once the thyroid function parameters had normalized, she was discharged from the hospital.

\section{Discussion}

The risk factors for thromboembolic incidents may be either inherited or acquired, the most important of which are tumors and some types of surgery ${ }^{5}$. A previous study has reported that $18 \%$ of patients who experienced VTE for the first time had malignant disease, $23 \%$ had undergone surgery in the last two months, $15 \%$ developed it during medical illness, $2 \%$ had severe trauma, and $41 \%$ of cases were idiopathic ${ }^{6}$. Other risk factors for VTE include previous thromboembolic incident, immobility, female sex, obesity, thrombophilia, antiphospholipid syndrome, psychotropic drugs, oral contraceptives, hyperhomocysteinemia, and other hemostatic abnormalities ${ }^{7}$. Pulmonary embolism caused by hyperthyroidism is rarely diagnosed. A 7-year casecontrol study has suggested that elevated levels of fT4 in patients is a predisposing factor for unprovoked VTE, and conversely, that lower levels of fT4 may be protective $^{8}$. It is probable that the risk of VTE associated with fT4 levels reflects thyroid hormone-induced synthesis and secretion of coagulation factors, particularly alterations in factor VIII synthesis and secretion, high concentrations of which are an independent risk factor for $\mathrm{VTE}^{7-10}$. Patients with hyperthyroidism have also elevated levels of factor VIII, von Willebrand factor and ristocetin cofactor activity, all of which promote clot formation. Several other pathophysiological mechanisms have been suggested to explain the relationship between thyroid hormone excess and hemostasis. A possible mechanism is directly via gene transcription in liver and endothelial cells, or possibly indirectly through increased beta-adrenergic action ${ }^{10}$. A 5-year comprehensive nationwide study conducted in Taiwan concluded that patients with hyperthyroidism had a 2.3 times greater risk of developing pulmonary embolism in the next year than the cohort comparison group $^{11}$.

\section{Conclusion}

This case report emphasizes the importance of timely diagnosis of hyperthyroidism as a rare but still possible cause of pulmonary embolism. Recognition of 
specific/frequent signs and symptoms of pulmonary embolism, as well as concomitant thyroid gland function assessment could help in early therapy introduction to improve the outcomes.

\section{References}

1. Tarbox AK, Swaroop M. Pulmonary embolism. Int J Crit Illn Inj Sci. 2013;3(1):69-72. doi: 10.4103/2229-5151.109427.

2. Lavorini F, Di Bello V, De Rimini ML, Lucignani G, Marconi L, Palareti G, et al. Diagnosis and treatment of pulmonary embolism: a multidisciplinary approach. Multidiscip Respir Med. 2013;8(1):75. doi: 10.1186/2049-6958-8-75.

3. Lin HC, Yang LY, Kang JH. Increased risk of pulmonary embolism among patients with hyperthyroidism: a 5-year follow-up study. J Thromb Haemost. 2010;8(10):2176-81. doi: 10.1111/j.1538-7836.2010.03993.

4. Konstantinides SV, Meyer G, Becattini C, Bueno H, Geersing GJ, Harjola VP, et al. 2019 ESC Guidelines for the diagnosis and management of acute pulmonary embolism developed in collaboration with the European Respiratory Society (ERS). Eur Heart J. 2020;41(4):543-603. doi: 10.1093/eurheartj/ ehz405.

5. Rosendaal FR. Causes of venous thrombosis. Thromb J. 2016; 14(1):24. doi: 10.1186/s12959-016-0108.
6. White RH. The epidemiology of venous thromboembolism. Circulation. 2003;107(23):4-8. doi: 10.1161/01.CIR.0000078 468.11849.66.

7. van Zaane B1, Squizzato A, Huijgen R, van Zanten AP, Fliers $\mathrm{E}$, Cannegieter SC, et al. Increasing levels of free thyroxine as a risk factor for a first venous thrombosis: a case-control study. Blood. 2010;115(22):4344-9. doi: 10.1182/blood-2009 $-11-253724$.

8. Koster T, Blann AD, Briët E, Vandenbroucke JP, Rosendaal FR. Role of clotting factor VIII in effect of von Willebrand factor on occurrence of deep-vein thrombosis. Lancet. 1995; 345(8943):152-5. doi: 10.1016/s0140-6736(95)90166-3.

9. Stuijver DJ, van Zaane B, Romualdi E, Brandjes DP, Gerdes VE, Squizzato A. The effect of hyperthyroidism on procoagulant, anticoagulant and fibrinolytic factors: a systematic review and meta-analysis. Thromb Haemost. 2012;108(6):1077-88. doi: 10.1160/TH12-07-0496.

10. Van Zaane B1, Squizzato A, Debeij J, Dekkers OM, Meijers JC, Van Zanten AP, et al. Alterations in coagulation and fibrinolysis after levothyroxine exposure in healthy volunteers: a controlled randomized crossover study. J Thromb Haemost. 2011;9(9):1816-24. doi: 10.1111/j.1538-7836.2011.04430.

11. Lin HC, Yang LY, Kang JH. Increased risk of pulmonary embolism among patients with hyperthyroidism: a 5-year followup study.J Thromb Haemost. 2010;8(10):2176-81. doi: 10.1111 /j.1538-7836.2010.03993.x.

Sažetak

\title{
ISTODOBNA DUBOKA VENSKA TROMBOZA I PLUĆNA EMBOLIJA UDRUŽENA S HIPERTIREOZOM: PRIKAZ SLUČAJA
}

\author{
J. Katić, A. Katić, K. Katić, D. Duplančić i M. Lozo
}

Različiti poremećaji koagulacije ponekad se povezuju s bolestima štitnjače, najčešće hipertireozom. Većina dosadašnjih radova je usredotočena na rizik duboke venske tromboze kod takvih bolesnika, dok je u vrlo malom broju radova opisana povezanost hipertireoze i plućne embolije. Prikazuje se slučaj 43-godišnje bolesnice s dugogodišnjom nekontroliranom hipertireozom i posljedičnim akutnim venskim tromboembolizmom. Vjerojatni patofiziološki mehanizam uključuje oštećenje endotela, smanjenje fibrinolitičke aktivnosti i povećanu razinu faktora koagulacije. Klinička i laboratorijska evaluacija štitnjače preporučljiva je u bolesnika s neprovociranim tromboembolijskim događajem.

Ključne riječi: Hipertireoza; Plućna embolija; Venska tromboembolija; Duboka venska tromboza 